Atmos. Chem. Phys., 19, 13325-13339, 2019

https://doi.org/10.5194/acp-19-13325-2019

(C) Author(s) 2019. This work is distributed under

the Creative Commons Attribution 4.0 License.

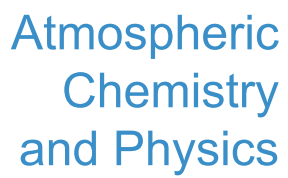

(c) (P)

\title{
Diurnal cycle of iodine, bromine, and mercury concentrations in Svalbard surface snow
}

\author{
Andrea Spolaor $^{1}$, Elena Barbaro ${ }^{1}$, David Cappelletti ${ }^{2}$, Clara Turetta ${ }^{1}$, Mauro Mazzola $^{3}$, Fabio Giardi $^{4}$, \\ Mats P. Björkman ${ }^{5}$, Federico Lucchetta ${ }^{6}$, Federico Dallo ${ }^{1}$, Katrine Aspmo Pfaffhuber ${ }^{7}$, Hélène Angot ${ }^{8}$, \\ Aurelien Dommergue ${ }^{9}$, Marion Maturilli ${ }^{10}$, Alfonso Saiz-Lopez ${ }^{11}$, Carlo Barbante ${ }^{6,1}$, and Warren R. L. Cairns ${ }^{1}$ \\ ${ }^{1}$ Institute of Polar Science, ISP-CNR, Campus Scientifico Via Torino 155, 30172 Mestre, Venice, Italy \\ ${ }^{2}$ Dipartimento di Chimica, Biologia e Biotecnologie, Università degli Studi di Perugia, 06123 Perugia, Italy \\ ${ }^{3}$ Institute of Polar Science, ISP-CNR, Via P. Gobetti 101, Bologna, Italy \\ ${ }^{4}$ Chemistry Department - Analytical Chemistry, Scientific Pole, University of Florence, Via della Lastruccia 3, \\ 50019 Sesto Fiorentino (Florence) Italy \\ ${ }^{5}$ Department of Earth Sciences, University of Gothenburg, P.O. Box 460, 40530 Gothenburg, Sweden \\ ${ }^{6}$ Department of Environmental Sciences, Informatics and Statistics, Ca' Foscari University of Venice, \\ Santa Marta - Dorsoduro 2137, 30123 Venice, Italy \\ ${ }^{7}$ NILU - Norwegian Institute for Air Research, Kjeller, Norway \\ ${ }^{8}$ Institute of Arctic and Alpine Research (INSTAAR), University of Colorado, Boulder, USA \\ ${ }^{9}$ Institut des Géosciences de l'Environnement, Univ. Grenoble Alpes, CNRS, IRD, Grenoble INP, 38000 Grenoble, France \\ ${ }^{10}$ Alfred Wegener Institute, Helmholtz Centre for Polar and Marine Research, Potsdam, Germany \\ ${ }^{11}$ Department of Atmospheric Chemistry and Climate, Institute of Physical Chemistry Rocasolano, CSIC, Madrid, Spain
}

Correspondence: Andrea Spolaor (andrea.spolaor@unive.it)

Received: 25 March 2019 - Discussion started: 19 June 2019

Revised: 26 September 2019 - Accepted: 1 October 2019 - Published: 29 October 2019

\begin{abstract}
Sunlit snow is highly photochemically active and plays a key role in the exchange of gas phase species between the cryosphere and the atmosphere. Here, we investigate the behaviour of two selected species in surface snow: mercury (Hg) and iodine (I). Hg can deposit year-round and accumulate in the snowpack. However, photo-induced re-emission of gas phase $\mathrm{Hg}$ from the surface has been widely reported. Iodine is active in atmospheric new particle formation, especially in the marine boundary layer, and in the destruction of atmospheric ozone. It can also undergo photochemical re-emission. Although previous studies indicate possible post-depositional processes, little is known about the diurnal behaviour of these two species and their interaction in surface snow. The mechanisms are still poorly constrained, and no field experiments have been performed in different seasons to investigate the magnitude of re-emission processes Three sampling campaigns conducted at an hourly resolution for $3 \mathrm{~d}$ each were carried out near Ny-Ålesund (Svalbard) to study the behaviour of mercury and iodine in surface snow
\end{abstract}

under different sunlight and environmental conditions $(24 \mathrm{~h}$ darkness, $24 \mathrm{~h}$ sunlight and day-night cycles). Our results indicate a different behaviour of mercury and iodine in surface snow during the different campaigns. The day-night experiments demonstrate the existence of a diurnal cycle in surface snow for $\mathrm{Hg}$ and iodine, indicating that these species are indeed influenced by the daily solar radiation cycle. Differently, bromine did not show any diurnal cycle. The diurnal cycle also disappeared for $\mathrm{Hg}$ and iodine during the $24 \mathrm{~h}$ sunlight period and during $24 \mathrm{~h}$ darkness experiments supporting the idea of the occurrence (absence) of a continuous recycling or exchange at the snow-air interface. These results demonstrate that this surface snow recycling is seasonally dependent, through sunlight. They also highlight the non-negligible role that snowpack emissions have on ambient air concentrations and potentially on iodine-induced atmospheric nucleation processes. 


\section{Introduction}

Polar regions are being increasingly studied for their important roles in global climate and atmospheric chemical cycles. Multiple studies have improved our understanding of atmospheric processes in polar regions, ranging from new particle formation processes (Dall'Osto et al., 2017; Sipilä et al., 2016), ozone destruction processes (Saiz-Lopez et al., 2007; Simpson et al., 2007), the role of halogens in polar atmospheric processes (Saiz-Lopez and von Glasow, 2012; Spolaor et al., 2013a), the mercury cycle (Angot et al., 2016a; Aspmo et al., 2005; Brooks et al., 2006; Dommergue et al., 2003a; Durnford and Dastoor, 2011; Skov et al., 2006) to atmospheric transport and deposition of natural and anthropogenic compounds (Moroni et al., 2015, 2017; Udisti et al., 2016; Zangrando et al., 2013). The polar regions are characterized by periods with $24 \mathrm{~h}$ of continuous solar radiation (April to September in the Arctic), periods when the night and day cycle is present (February to March and September to October in the Arctic) and periods of continuous darkness (November to January in the Arctic), the so-called polar night. The different periods have completely different environmental conditions depending on the incoming solar radiation, with variables such as sea ice presence or biological activity being radically altered by sunlight. One important aspect is snow cover. Annual snow is present, on average, for almost 9 months of the year and represents an important environmental component of polar regions. In Svalbard, the snow starts to accumulate in October and remains until the end of May when the melting season begins (Førland et al., 2011). However, with Arctic temperatures rising (Maturilli et al., 2013), the length of the snow cover has diminished (Hansen et al., 2014), with direct consequences for the environment of the Svalbard archipelago, such as glacier mass loss, permafrost thawing, and disturbances of the local fauna (Karner et al., 2013; Kohler and Aanes, 2004; Kohler et al., 2007; Westermann et al., 2011). The annual snow layer is an extremely dynamic part of the cryosphere and can be defined as the snow accumulated and present on the ground during the whole year (Spolaor et al., 2016a). The characteristics of the annual snow strata are strongly dependent on climate conditions and may influence food access for animals that rely on food sources below the snow (Kohler and Aanes, 2004). From a chemical point of view, snow is a sink for an impressive number of chemical compounds (natural and anthropogenic) and elements (Björkman et al., 2013; Gabrieli et al., 2011; Vecchiato et al., 2018). Specific compounds and elements accumulate during the winter can undergo photoactivation and can be re-emitted into the atmosphere (Angot et al., 2016c; Spolaor et al., 2014), while taking part in numerous geochemical and biological cycles (Björkman et al., 2014) during spring and summer. Mercury ( $\mathrm{Hg}$ ) and iodine (I) are two elements that can be photoactivated and released from the snowpack. Mercury is a heavy metal with a known toxicity present in the environment in several different chem- ical forms. It is reactive in the environment and undergoes photochemical reactions that change its speciation and chemical behaviour (Dommergue et al., 2010; Durnford and Dastoor, 2011; Saiz-Lopez et al., 2018; Steffen et al., 2002). Mercury in its oxidized form can be deposited onto the snowpack, increasing $\mathrm{Hg}$ concentrations in the upper snow strata (Obrist et al., 2017). Once present in the snowpack, Hg is very labile, and it can be reduced back to elemental $\mathrm{Hg}(\mathrm{Hg}(0))$ and undergo dynamic exchange with the atmosphere (Song et al., 2018; Spolaor et al., 2018; Steffen et al., 2002). The role of the snowpack is crucial in the mercury cycle in polar regions since it acts as both a sink (deposition, accumulation) and a source (re-emission). Several studies have already been carried out in the polar regions with the aim of determining the extent of mercury recycling between the surface snow and the lower atmosphere (Angot et al., 2016c; Brooks et al., 2008, 2006; Dommergue et al., 2012; Douglas et al., 2008; Han et al., 2014; Obrist et al., 2017; Wang et al., 2016). It has been shown that surface Arctic snow could lose up to $90 \%$ of its total $\mathrm{Hg}$ content within $48 \mathrm{~h}$ (Poulain et al., 2004). Similar, re-emission/loss rates of $\mathrm{Hg}$ from snow surface $(35 \%-50 \%)$ and drifting snow $(65 \%-75 \%)$ over $10.5 \mathrm{~h}$ have been suggested in chamber experiments (Sherman et al., 2010) while, in a study performed on the Antarctic Plateau, Spolaor et al. (2018) suggest a loss of $90 \%$ of mercury in the upper snow layer within a few hours. High gaseous elemental mercury (GEM) emission from the snowpack has also been determined at Station North (Greenland), where the emission flux can rise up to $190 \mathrm{ng} \mathrm{m}^{-2} \mathrm{~min}^{-1}$ (Kamp et al., 2018). Similar to mercury, iodine can undergo photochemical activation in surface snow resulting in its presence in the surrounding atmosphere (Frieß et al., 2010; Spolaor et al., 2014). Several studies aimed at understanding the behaviour of iodine in the Arctic region from a paleo-perspective using ice core archives (Cuevas et al., 2018; Spolaor et al., 2016b), and field (atmospheric and snow) experiments (Frieß et al., 2010; Gilfedder et al., 2007). The role of iodine in new particle formation as well in ozone destruction is currently under investigation (Allan et al., 2015; Saiz-Lopez et al., 2012, 2006; Sipilä et al., 2016) since it could have a direct effect on the radiative budget of polar areas. Up to now, it was believed that iodine was mainly associated with biological emissions; however, recent studies have underlined the increase in ocean inorganic emissions (tripled since 1950) connected with the increase in anthropogenic ozone via reactions over the ocean surface (Cuevas et al., 2018). Like mercury, iodine could be released from surface snow and directly participate in specific processes within the marine boundary layer, particularly in new particle formation. Little information exists on the behaviour of mercury and iodine in surface snow during different seasons. Laboratory experiments were carried out to understand light-induced processes regarding $\mathrm{Hg}$ and iodine (Durnford and Dastoor, 2011; Saiz-Lopez et al., 2012; Spolaor et al., 2013b). However, a few experiments have been carried out in the field, with the specific aim of understand- 
ing the diurnal dynamics of these elements in surface snow (Dommergue et al., 2003b; Ferrari et al., 2005; Spolaor et al., 2018). The unique high temporal-resolution experiments presented aim to improve our understanding of the behaviour of these elements in the upper snow layers $(0-3 \mathrm{~cm})$ under different light and atmospheric conditions to investigate their short-term (diurnal) variation.

\section{Methods}

The experiments were conducted in the vicinity of $\mathrm{Ny}$ Allesund, in the snowfield behind the Gruvebadet aerosol site (Fig. 1). This area has a homogeneously flat surface without specific elevation changes or obstacles that might interfere with snow deposition or wind-blown redistribution. This area is approximately $1 \mathrm{~km}$ from the coastline of the Kongsfjorden and about $400 \mathrm{~m}$ from the Zeppelin mountain. The Gruvebadet snow field is located to the south of Ny-Ålesund at an elevation of the $80 \mathrm{~m}$ a.s.1. (Fig. 1), while the prevailing winds are mainly from east and south-east, minimizing possible influences from station activities.

\subsection{Sampling period and strategy}

Surface snow samples were collected in the vicinity of NyAlesund, specifically in the snow field behind the Gruvebadet Aerosol Laboratory (Fig. 1). Three experiments were conducted: two in spring (2015 and 2016) and one in winter (2017). In 2015, we performed the first surface experiment (hereafter called the "2015 experiment") between 28 April and 1 May. This period was characterized by $24 \mathrm{~h}$ of sunlight (incoming solar radiation ranged from a minimum of $25 \mathrm{~W} \mathrm{~m}^{-2}$ to a maximum of $456 \mathrm{~W} \mathrm{~m}^{-2}$ ). In 2016, a second experiment (hereafter called the "2016 experiment") was carried out between 6 and 9 April when the night and day cycle was still present at $\mathrm{Ny}$-Ålesund (incoming solar radiation between 0 and $227 \mathrm{~W} \mathrm{~m}^{-2}$ ). The last experiment was conducted during the polar night, between 24 and 29 January 2017 (hereafter called the "2017 experiment") with the complete absence of incoming solar radiation.

The 2017 experiment was conducted during the second half of January when full snow cover is guaranteed (LópezMoreno et al., 2016). In December, snow cover in the Spitsbergen area is not homogeneously distributed. The ground could still be partially exposed, meaning that locally generated windblown dust could affect the trace element concentrations in the snow surface. The spring period selected for the 2016 experiment had two main characteristics: a welldefined night and day cycle without a long sunset, avoiding possible incoming solar radiation by diffraction processes over the horizon. There was also the possibility observing atmospheric mercury depletion events (AMDEs) connected with bromine explosion events (Lu et al., 2001; Moore et al., 2014; Schroeder and Munthe, 1998). Unfortunately, these events were not observed as the northern coast of Svalbard was virtually ice free by the time we started sampling. The 2015 experiment was scheduled to end at the beginning of May, when we have a full $24 \mathrm{~h}$ of sunlight reaching the snow surface, but temperatures are still below freezing, avoiding or minimizing the confounding effects of snowpack melt or collapse on surface photochemical processes and gaseous mercury transport in the interstitial air. The meteorological conditions throughout all the experiments are within the expected local conditions for the time of year.

To determine the diurnal variation and the rates of the expected changes in iodine and mercury concentrations, a high temporal-resolution (hourly) sampling strategy was adopted. An area of approximately $2 \mathrm{~m} \times 2 \mathrm{~m}$ was delimited for surface snow sampling, and all samples were collected inside this delimited area. At the beginning of the experiment, six samples were collected to evaluate the spatial variability of mercury, iodine, bromine (bromine is limited to the 2016 experiment), and sodium in surface snow within the delimited snowfield. Afterwards, surface snow (the first $3 \mathrm{~cm}$ ) was sampled with an hourly resolution for 3 consecutive days. The upper $3 \mathrm{~cm}$ were chosen as this is the snow layer that is most influenced by the surrounding atmospheric conditions, and, in case of snowfall, by deposition (Spolaor et al., 2018). This choice also minimizes the effect of different physical snow conditions (density and crystal shape and size). Although reemission of mercury and iodine from lower snow strata could influence the gaseous concentrations in the snow interstitial air (Faïn et al., 2007), it is much less likely to have a direct effect on snow concentrations due to its poor solubility in water. During snow sampling, the temperature of surface snow was also measured. To minimize spatial variability, samples were collected following a straight line leaving about $5 \mathrm{~cm}$ between each of the sampling points. After collection, the snow samples were stored at $-20^{\circ} \mathrm{C}$ in dark conditions and transported to the Venice IDPA-CNR laboratories. The samples were never melted or exposed to direct sunlight until analysis.

\subsection{Meteorological measurements}

Meteorological and radiation conditions were monitored at the Amundsen-Nobile Climate Change Tower (Mazzola et al., 2016), located about $500 \mathrm{~m}$ west of the sampling site, and the AWIPEV (Alfred Wegener Institute for Polar and Marine Research, AWI, and the French Polar Institute Paul Emile Victor, IPEV) observatory (Maturilli et al., 2013) is located about $800 \mathrm{~m}$ north of the sampling site. No meteorological measurements are present in the sampling area. Temperature and relative humidity were measured at $2 \mathrm{~m}$ above ground level and were considered as representative of the atmosphere just above the snow surface, while wind speed and direction were measured at $10 \mathrm{~m}$ above ground. Incoming solar radiation was measured at the top of the CCT (Amundsen-Nobile Climate Change Tower; $33 \mathrm{~m}$ ); this value 
(a)

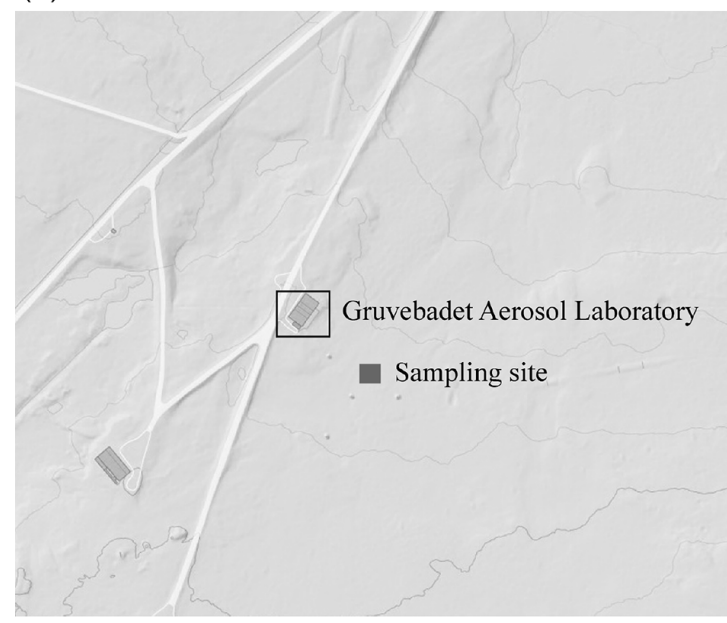

(b)

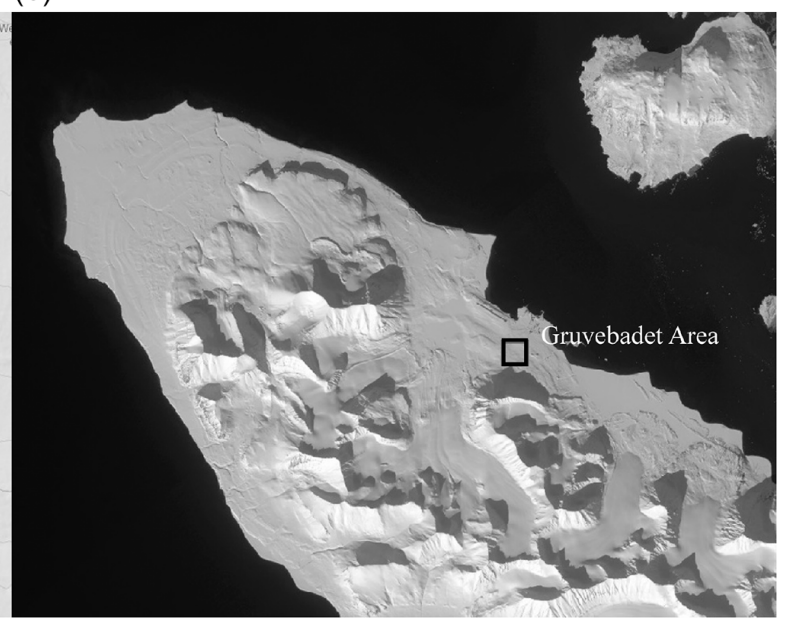

Figure 1. Location of the experimental area in the proximity of Ny-Ålesund research village (black rectangle - b) and the site of experiments (grey rectangle - a) behind the Gruvebadet Aerosol Laboratory. Maps from https://toposvalbard.npolar.no/ (last access: 26 October 2019).

was not influenced by reflections from the structure. Oneminute data were used to obtain hourly averages. Snow accumulation data were obtained by measuring the height of four plastic poles located at the extremities of the snow sampling field. Precipitation data were recorded in Ny-Ålesund by the Norwegian Meteorological Institute (station no. 99910) and downloaded through the eKlima database (http://eklima.no, last access: 26 October 2019).

\subsection{Snow mercury analysis}

Total Hg concentrations in surface snow samples were determined using a Thermo Element inductively coupled plasma sector field mass spectrometry (ICP-SFMS Element XR, Thermo-Fisher, Bremen, Germany) in low-resolution scanning mode using ${ }^{202} \mathrm{Hg}$ as the analytical mercury mass, with 10 replicates per sample measurement. The instrument was calibrated using standards prepared from a mono-elemental $\mathrm{Hg}$ solution $\left(\right.$ TraceCert $^{\circledR}$, purity grade, Sigma-Aldrich, MO, USA). Hg calibration standards were re-analysed every 10 samples as a quality control check. The percent relative standard deviation $(n=10)$ ranged from $0.5 \%$ at $500 \mathrm{pg} \mathrm{g}^{-1}$ to $10 \%$ at $1 \mathrm{pg} \mathrm{g}^{-1}$ and amounted to $2.6 \%$ on average. Considering the high volatility and instability of $\mathrm{Hg}$ in solution, the samples were acidified at $2 \% v / v$ with ultrapure hydrochloric acid before they were melted and analysed. Each sample was weighed and the exact amount of $\mathrm{HCl}$ was added to reach a final concentration of $2 \%$ (Planchon et al., 2004; Spolaor et al., 2018).

\subsection{Snow iodine, sodium, and bromine analysis}

Halogens ( $\mathrm{I}$ and $\mathrm{Br}$ ) and sodium analyses were conducted on non-acidified samples. Total sodium (Na), iodine (I), and bromine $(\mathrm{Br})$ concentrations were determined by ICP-SFMS
(Spolaor et al., 2016c). Each analytical run started and ended with an ultra-pure water (UPW) cleaning session of $3 \mathrm{~min}$ to ensure a stable background level throughout the analysis. The external standards that were used to calibrate the analytes were prepared by diluting a $1000 \mathrm{ppm}$ stock IC (ion chromatography) standard solution (TraceCERT ${ }^{\circledR}$ purity grade, Sigma-Aldrich, MO, USA). The standard concentrations ranged between 10 and $4000 \mathrm{ng} \mathrm{g}^{-1}$ for sodium, 0.01 and $1 \mathrm{ng} \mathrm{g}^{-1}$ for iodine and 0.5 and $20 \mathrm{ng} \mathrm{g}^{-1}$ for bromine. The residual standard deviation (RSD) was low for all analytes, the halogens ranged between $1 \%$ and $2 \%$ and $2 \%$ and $5 \%$ for $\mathrm{Br}$ and I, respectively, and the RSD was $3 \%-4 \%$ for sodium.

\subsection{Atmospheric mercury measurements}

Atmospheric mercury concentrations were obtained from the Zeppelin Observatory located at $474 \mathrm{~m}$ a.s.l, less than $1 \mathrm{~km}$ away from the sampling site (Fig. 1). GEM was monitored using a Tekran $2537 \mathrm{Hg}$ vapour analyser as described by Aspmo et al. (2005) and as summarized here: ambient air was sampled at $1.5 \mathrm{~L} \mathrm{~min}^{-1}$ through a Teflon filter via a heated sampling line. A soda-lime trap was mounted in-line before the instrument filter. $\mathrm{Hg}$ in the air is pre-concentrated for $5 \mathrm{~min}$ by amalgamation on two parallel gold cartridges, which alternate between collection and thermal desorption, followed by AFS (atomic fluorescence spectrometric) detection. The instrument was auto-calibrated every $25 \mathrm{~h}$ using an internal $\mathrm{Hg}$ permeation source, whose accuracy was verified during routine site audits that include manual injections of $\mathrm{Hg}$ from an external source (Aspmo et al., 2005). The measurements at Zeppelin were the only GEM measurements available in the Ny-Ålesund area. Although GEM measurements at the snow sampling site would have been more reliable in determining possible interactions between snow and 
atmospheric mercury, it was not possible to set up an instrument at the site. We assume that the snow reactions occurring at the sampling site at $40 \mathrm{~m}$ a.s.l. are of the same order of magnitude as those occurring in the snow layers surrounding Zeppelin station.

\section{Results}

The 2015 and 2016 experiments were characterized by similar atmospheric conditions (except for the incoming solar radiation), while during the 2017 experiment a storm approached $\mathrm{Ny}-\mathrm{A} l$ lesund during the first $12 \mathrm{~h}$ of the experiment with strong winds lasting for the first $24 \mathrm{~h}$ of the experiment. During the 2015 experiment under full-day conditions, the average air temperature ranged between -10 and $-6{ }^{\circ} \mathrm{C}$ and the surface snow temperature range between -13 and $-5^{\circ} \mathrm{C}$, showing a diurnal variability connected with changes in the incoming solar radiation (Fig. 2). Incoming solar radiation ranged from a minimum of $25 \mathrm{~W} \mathrm{~m}^{-2}$ to a maximum of $450 \mathrm{~W} \mathrm{~m}^{-2}$. Wind speed was almost constant and remained below $3 \mathrm{~m} \mathrm{~s}^{-1}$ during most of the experiment, except for a few hours at the beginning when it exceeded $3 \mathrm{~m} \mathrm{~s}^{-1}$. Snowfall ( $1 \mathrm{~cm}$ net accumulation on the ground) occurred on 30 April between 03:00 and 11:00 (Fig. 2, pink shading). A snow event, causing a net accumulation of $1 \mathrm{~cm}$ of snow, also occurred during the 2016 experiment (Fig. 3, pink shading) when day and night periods were present. The snow event occurred on 9 April between 10:00 and 15:00. During the 2016 experiment, conducted between 6 and 9 April, the snow temperature was not registered due a technical problem with the temperature probe installed in the snow. Air temperature ranged between -7 and $-3{ }^{\circ} \mathrm{C}$ and solar radiation between zero at nighttime and a maximum of $227 \mathrm{~W} \mathrm{~m}^{-2}$. As for the first experiment, wind speed was below $3 \mathrm{~m} \mathrm{~s}^{-1}$, minimizing the effect of blowing snow. Wind direction was almost constant and prevailing from east. The GEM and the surface snow mercury datasets were de-trended to emphasize the diurnal variation and remove the decreasing trend present in both datasets. The de-trended series were obtained calculating the linear regression line for both series and subtracting this value from the data. Figure $3 e$ reports the detrended mercury dataset while Fig. 4 shows the raw data and the methods used to remove the trend. The 2017 winter experiment (Fig. 5) was characterized by a snowstorm that occurred on 24 January (10 h after the experiment began; pink shading). Differently to the previous experiments, the wind speed averaged $9 \mathrm{~m} \mathrm{~s}^{-1}$ during the storm, with a maximum speed of $16 \mathrm{~m} \mathrm{~s}^{-1}$ (Fig. 5, orange line). Strong winds can redistribute surface snow and significantly change chemical concentrations. For these reasons, the winter experiment began on 24 January and ended on 29 January for $5 \mathrm{~d}$ in total, compared the $3 \mathrm{~d}$ adopted for the 2015 and 2016 experiment. The length of the experiment was extended of $2 \mathrm{~d}$ to minimize the impact of the strong wind and snowfall that oc- curred at the beginning of the experiment. Air temperatures ranged from between -17 and $-3{ }^{\circ} \mathrm{C}$, while snow temperatures ranged between -25 and $-10^{\circ} \mathrm{C}$ (Fig. 5b). One important issue that could confound the results obtained by surface sampling is spatial variability. Spatial variability was tested during the three experiments and specifically for the four elements investigated. Six surface snow aliquots were collected at the beginning of each experiment within the delimited area at the same time. The results obtained show that for sodium, bromine, and mercury, spatial variability can explain $10 \%$ of the variability, whilst for iodine the variability was of the order of $5 \%$. Concentrations detected during the three experiments show different background levels (Table 1) for total iodine, sodium, mercury, and gaseous elemental mercury (Br was measured only during the 2016 experiment). For sodium, the highest concentration was detected during the 2015 (full-day) experiment where concentrations in surface snow averaged $3500 \mathrm{ng} \mathrm{g}^{-1}$. The lowest sodium concentrations were determined during the winter period with concentrations of around $1500 \mathrm{ng} \mathrm{g}^{-1}$. For iodine the trend was the opposite, with highest concentrations in winter $\left(0.38 \mathrm{ng} \mathrm{g}^{-1}\right)$ and the lowest during the $24 \mathrm{~h}$ sunlight period $\left(0.15 \mathrm{ng} \mathrm{g}^{-1}\right)$. For total mercury, the minimum concentration was found in early spring (0.007 $\mathrm{ng} \mathrm{g}^{-1}, 2016$ experiment) while the highest values were detected during 2015 (full light) and 2017 winter experiment (on average $0.010 \mathrm{ng} \mathrm{g}^{-1}$ for 2015 and $0.009 \mathrm{ng} \mathrm{g}^{-1}$ for 2017). Gaseous elemental mercury during the experiments had the highest concentration during springtime, when $24 \mathrm{~h}$ incoming solar radiation is present $\left(1.45 \mathrm{ng} \mathrm{m}^{-3}\right)$ while the lowest value has been detected during the polar night $\left(1.28 \mathrm{ng} \mathrm{m}^{-3}\right)$. The average concentration during the experiment is only representative of specific periods in the experiment and should not be considered as a reference concentration for a specific season. The experimental periods were chosen to reduce the possibility of snowfall deposition during the experiment and to avoid periods with strong wind and subsequent windblown snow transport (the main reason why the winter experiment was lengthened to $5 \mathrm{~d})$. This was all done to minimize the effects of meteorological parameters on our results and make the experiments more comparable. We cannot exclude that the behaviour that we found for iodine, mercury, and bromine could be significantly different during the specific season or periods (such as for example during an AMDE) or when meteorological conditions such as snow deposition frequency and amount, wind strength, and cloud coverage were different. Some indications emerged, especially for iodine, which showed the highest concentrations during the polar night in the absence of solar radiation. Considering iodine (inorganic and organic) is mainly emitted by oceanic processes, iodine concentrations were normalized to sodium concentrations to obtain iodine enrichment $\left(\mathrm{I}_{\mathrm{enr}}\right)$ compared to the bulk seawater abundance. This is defined as $\mathrm{I}_{\mathrm{enr}}=\mathrm{I}_{\text {snow }} \times\left(\mathrm{Na}_{\text {snow }} \times[\mathrm{I} / \mathrm{Na}]_{\mathrm{sw}}\right)$, where $\mathrm{I} / \mathrm{Na}=0.00000596$ (Millero et al., 2008), where "sw" is the measured seawater abundance. In the 2015 experiment 
(24 h sunlight), iodine had an average enrichment value of 5 , a value that exponentially increased (up to 190) during snowfall (Fig. 2), so if we consider the snowfall period, the mean value increases to 10 . The 2016 experiment (day-night) was characterized by a diurnal cycle for both mercury and iodine (and $I_{e n r}$ ) and by an average $I_{\text {enr }}$ value of 11 , with the lowest value during daytime and higher values detected during the night periods (Fig. 3). As for the 2015 experiment, the experiment conducted in 2016 was characterized by a snowfall event that significantly influenced the surface iodine concentration and its enrichment factor. During the 2016 experiment, snowfall caused the $\mathrm{I}_{\mathrm{enr}}$ to increase up to 300 . The rapid increase in iodine and its enrichment factor during snowfall was followed by a rapid decrease to the pre-snowfall (seasonal background value) concentration during the 2015 experiment (Fig. 2), whilst in the 2016 experiment the increased concentration and enrichment caused by the snowfall was most likely masked by the nighttime deposition (Fig. 3). Similar behaviour was measured for total mercury in surface snow samples, with an increase in concentration during snowfall followed by a rapid decrease in both experiments (Figs. 2 and 3). The winter experiment is characterized by the highest iodine enrichment values (47 on average), and, similar to the previous experimental results, the experiment was characterized by snowfall and strong winds during the first $24 \mathrm{~h}$. During the storm period in the winter experiment, we detected an increase in iodine concentrations (and $\mathrm{I}_{\text {enr }}$ up to 100); however, the difference in iodine enrichment between the snowfall periods and rest of samples collect was not statistically significant. The average elemental concentrations for each experiment are reported in Table 1.

\section{Discussion}

The behaviour of mercury and iodine in surface snow depends on the season and the amount of incoming solar radiation (Figs. 2, 3, 5). AMDEs can occur during the springtime causing large-scale deposition of mercury to the snowpack concurrently with ozone photochemistry and oxidation reactions involving bromine. During our spring experiments we have not observed any rapid decreases in GEM or increases in mercury concentrations in the surface snow. This indicates that no AMDE occurred during the sampling periods and that, especially for bromine, the main depositional source was from sea spray given the distance from the coastline $(<1 \mathrm{~km})$ and the positive correlation with Na (Table 2). This is in line with the findings of Angot et al. (2016a), who reported that AMDEs occur much less frequently at Zeppelin station than they do at Alert or Station North in Greenland.

During wintertime (Fig. 5), iodine behaves similarly to sodium. Sodium does not undergo photochemical processes in the snow and is often used to evaluate or correct for marine sea spray emission or deposition (Spolaor et al., 2014). During winter, iodine has higher concentrations and enrich-

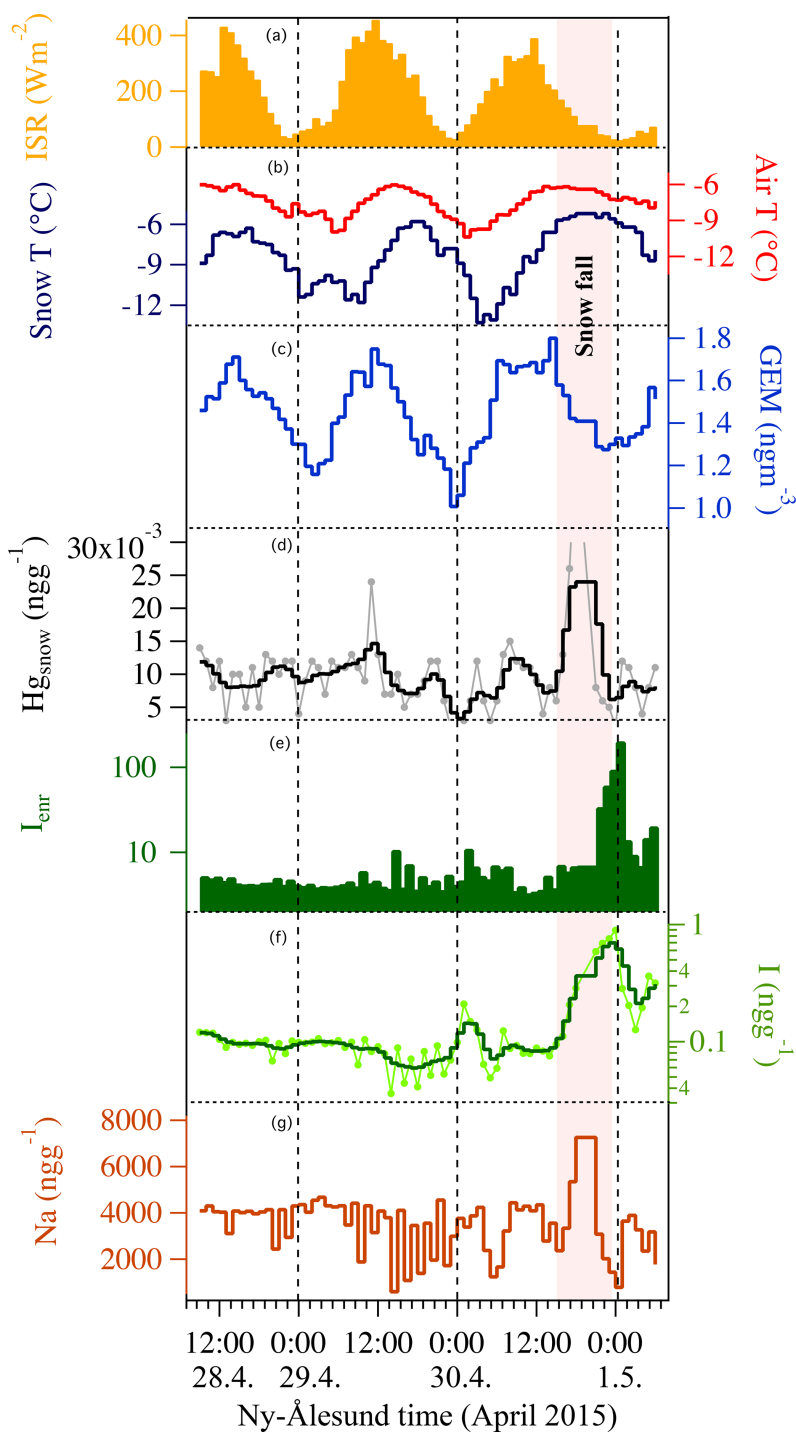

Figure 2. The 2015 experiment: continuous light conditions. The hourly sodium ( $\mathrm{g}$ - dark red) concentrations are connected with iodine concentrations (f - light green for the raw data and green for the three-point smoothing) except during the snowfall where the signals decouple. Iodine enrichment (e - dark green) demonstrates the effect of snowfall on iodine concentration in surface snow. Gaseous elemental mercury $(\mathbf{c}-$ blue) exhibits a diurnal pattern, while total mercury in surface snow ( $\mathbf{d}$ - grey line and black line three-point smoothing) does not. Snowfall occurrence is highlighted by the pink shading. Snow and air temperature $(\mathbf{b}-$ dark blue and red) show the diurnal cycle connected with incoming solar radiation (ISR) (a solid yellow). Wind speed is not shown since it was almost constant during the entire experiment. Dashed vertical lines indicate local midnight.

ment factors (compared to its seawater abundance based on the I/Na mass ratio). These higher values in surface snow could be due to the absence of photochemical activation by solar radiation. In the absence of photochemistry and with limited biological production in winter (Ardyna et al., 2013), 
Table 1. Concentration of iodine and its enrichment in surface snow $\left(\mathrm{I}_{\text {snow }}, \mathrm{I}_{\mathrm{enr}}\right)$, surface snow mercury $\left(\mathrm{Hg}_{\text {snow }}\right)$, atmospheric mercury $\left(\mathrm{Hg}_{\mathrm{atm}}\right)$, and surface snow sodium $\left(\mathrm{Na}_{\text {snow }}\right)$ during the different experiments. Concentrations and standard deviation (in brackets) are calculated for the entire dataset; an asterisk indicates that the concentration has been calculated without considering the snowfall events.

\begin{tabular}{lrrrrr}
\hline & $\mathrm{I}_{\text {snow }}\left(\mathrm{ng} \mathrm{g}^{-1}\right)$ & $\mathrm{Na}_{\text {snow }}\left(\mathrm{ng} \mathrm{g}^{-1}\right)$ & $\mathrm{Hg}_{\text {snow }}\left(\mathrm{ng} \mathrm{g}^{-1}\right)$ & $\mathrm{Hg}_{\text {atm }}\left(\mathrm{ng} \mathrm{m}^{-3}\right)$ & $\mathrm{I}_{\text {enr }}$ \\
\hline 2015 (day) & $0.147(0.162)$ & $3442(1180)$ & $0.010(0.006)$ & $1.45(0.18)$ & $10.7(25.5)$ \\
$2015^{*}$ & $0.090(0.027)$ & $3502(1030)$ & $0.009(0.004)$ & $1.46(0.19)$ & $4.59(1.43)$ \\
2016 (day-night) & $0.167(0.076)$ & $2041(777)$ & $0.007(0.008)$ & $1.35(0.13)$ & $25.7(46.4)$ \\
$2016^{*}$ & $0.142(0.057)$ & $2317(498)$ & $0.007(0.009)$ & $1.40(0.08)$ & $10.2(3.28)$ \\
2017 (night) & $0.382(0.175)$ & $1518(749)$ & $0.009(0.006)$ & $1.26(0.07)$ & $44.3(11.2)$ \\
$2017^{*}$ & $0.433(0.185)$ & $1786(770)$ & $0.008(0.004)$ & $1.26(0.06)$ & $41.8(8.40)$ \\
\hline
\end{tabular}

Table 2. Correlation coefficient between iodine and sodium, bromine and sodium (only 2016), and atmospheric and snow mercury. The correlation is calculated for the entire dataset. When the correlation is marked with an asterisk, this indicates that the correlation has been calculated without considering the snowfall events. During the 2016 experiment the correlation between $\mathrm{Hg}_{\text {snow }}$ and $\mathrm{Hg}_{\text {atm }} *{ }^{*}$ has been detrended to highlight the antiphase between $\mathrm{Hg}_{\mathrm{atm}}$ and $\mathrm{Hg}_{\text {snow }}$. The "+" and "-" indicate whether the association is positive or negative, and the values in parentheses are the $p$ values. $\mathrm{NA}=$ not available.

\begin{tabular}{rrrrrrr}
\hline & I vs. Na & I vs. Na & Br vs. Na & Br vs. Na* & Hg $_{\text {snow }}$ vs. $\mathrm{Hg}_{\text {atm }}$ & $\mathrm{Hg}_{\text {snow }}$ vs. $\mathrm{Hg}_{\text {atm }}{ }^{*}$ \\
\hline 2015 & $0.24(0.052)+$ & $0.63(>0.01)+$ & $\mathrm{NA}$ & $\mathrm{NA}$ & $0.18(0.13)+$ & $0.36(0.011)+$ \\
2016 & $0.21(0.041)+$ & $0.62(<0.01)+$ & $0.91(<0.01)+$ & $0.74(<0.01)+$ & $0.12(<0.01)+$ & $0.43(<0.01)+*$ \\
2017 & $0.90(<0.01)+$ & $0.89(<0.01)+$ & $\mathrm{NA}$ & $\mathrm{NA}$ & $0.22(0.05)+$ & $0.062(0.63)+$ \\
\hline
\end{tabular}

** De-trended $0.61(0.056)-$.

we expect to find enrichment values close to the seawater abundance. However, during the 2017 experiment, iodine had higher than expected enrichment values suggesting that (an) extra source(s), in addition to sea spray emission, may exist and that it might be dominant during winter. Saiz-Lopez et al. (2016) suggests that nighttime radical activation can occur. They indicate that the reaction of $\mathrm{HOI}$ with $\mathrm{NO}_{3}$, to yield $\mathrm{IO}+\mathrm{HNO}_{3}$, is possible under winter tropospheric conditions (Saiz-Lopez et al., 2016). The inclusion of this reaction, along with that of $\mathrm{I}_{2}+\mathrm{NO}_{3}$, has a number of significant implications, such as the nighttime activation of iodine radical chemistry that can cause an enhanced nighttime oceanic emissions of HOI and $I_{2}$ (Saiz-Lopez et al., 2016). Although typical $\mathrm{NO}_{x}$ levels are low in the Arctic, the reaction with NO3 could be relevant close to Arctic cities and under episodes of anthropogenic long-range transport of pollution to the Arctic. Sea spray aerosol droplets could absorb gas phase iodine emissions from the ocean surface (as suggested by the high correlation between total iodine and sodium, Fig. 5 and Table 2) and deposited on the surface snow causing the high iodine surface snow enrichment. This process, together with the absence of photoactivation that causes iodine loss from the snow surface, could explain the high level of iodine during the polar night.

In parallel to iodine, our experiments have focused on the rapid changes in mercury concentrations that could occur in surface snow during the polar night. This is because without these temporal resolution measurements, it is extremely difficult to determine which reactions might be occurring. During the first $24 \mathrm{~h}$ of the winter experiment (2017) we had strong winds remodelling the snow surface. Variations in surface mercury concentrations detected within the first $24 \mathrm{~h}$ may in part have been due to snowfall and physical artefacts caused by windblown snow redistribution. After the storm, total mercury concentrations in surface snow tended to stabilize until the end of the experiment. It should be noted that some oscillations in surface snow mercury concentrations and the ambient air above have been detected. Mercury in the snow rapidly decreased from 00:00 on the 24 January until noon on the same day and was associated with an increase in the atmospheric mercury concentration (Fig. 5). After this sharp increase, the GEM concentration decreased rapidly while the surface snow mercury increased. These two rapid events occurred within about $24 \mathrm{~h}$, supporting the idea of a connection and interchange between GEM and the mercury present in snow surface, even during nighttime. Nighttime mercury reactions have been thought to occur. Angot et al. (2016b) suggested that mercury deposition onto the snow surface in the dark could be due to several mechanisms, including gas phase oxidation, heterogeneous reactions, or dry deposition of $\mathrm{Hg}(0)$ (Angot et al., 2016b; Song et al., 2018). This hypothesis, however, is based on results obtained at Dome $\mathrm{C}$ on the Antarctic Plateau over the entire winter season, conditions very different to those in Svalbard. The average mercury surface snow concentrations detected during the winter experiment are comparable to those during the 2015 experiment (Fig. 2 and Table 1); this might be due, as for iodine, to the lack of light-induced snow re-emission, but it might also 


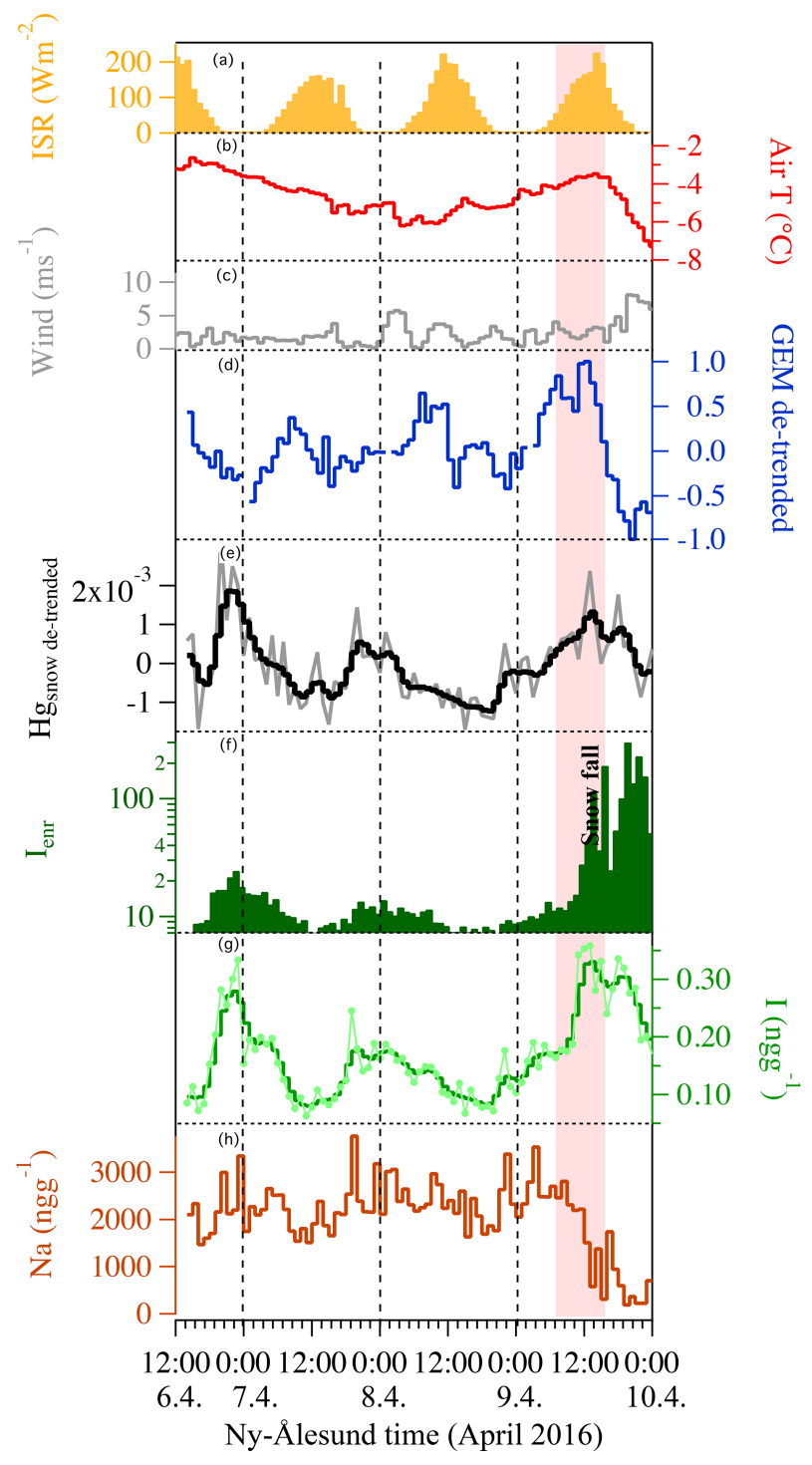

Figure 3. The 2016 experiment took place when a day and night cycle was available. Iodine concentration ( $\mathrm{g}$ - light green line for the raw data and green light for the three-point smoothing) exhibited a diurnal variability (except during the snowfall event), not detected for sodium (h - dark red line). The iodine enrichment factor (f dark green solid line) also exhibited a diurnal cycle and highlights the effect of snowfall on iodine concentration in surface snow (pink shading shows the snowfall event). De-trended GEM (d - blue line) and the surface snow de-trended total mercury concentrations (e grey lines for raw data and black line for the three-point smoothing) show opposing diurnal patterns. Additional information can be found in Fig. 4. Air temperature does not show a pronounced diurnal cycle (b - red line) connected with incoming solar radiation (ISR) (a-yellow solid). Wind speed is shown in grey (c). Dashed vertical lines indicate local midnight.

be caused by different background concentrations independent of any seasonal effect. (a)

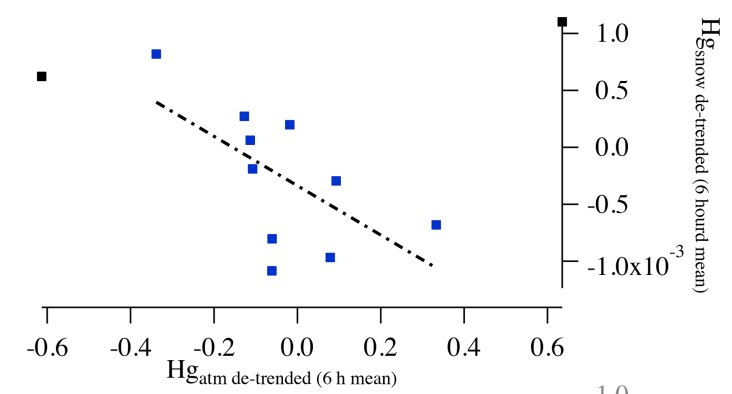

(b)
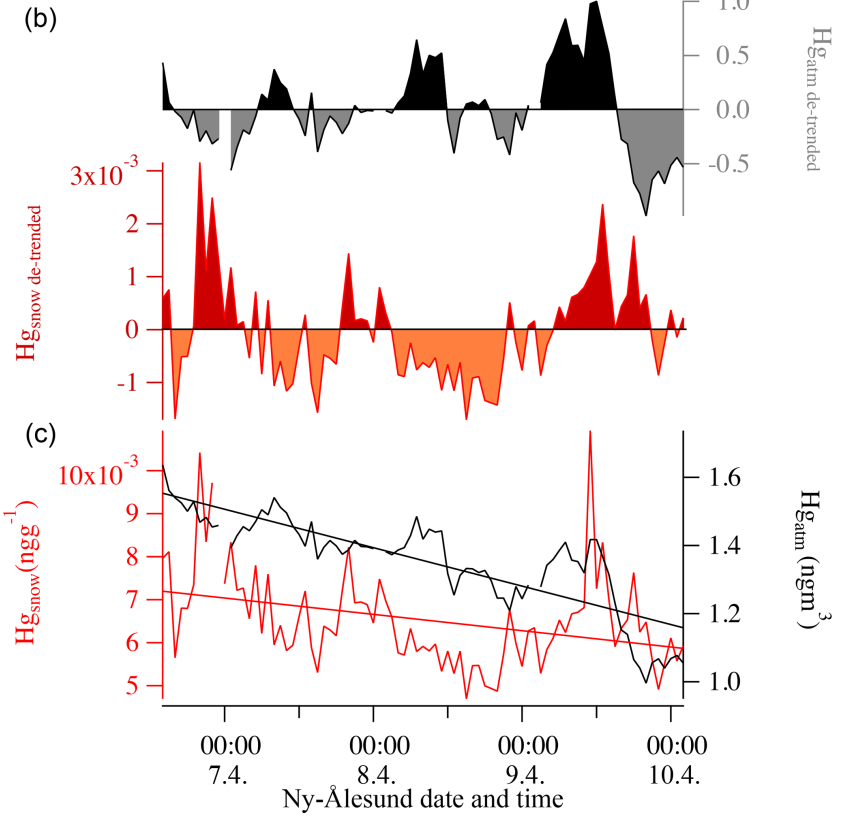

Figure 4. Panel (c) shows the two series without any statistical treatment $\left(\mathrm{Hg}_{\text {atm }}\right.$ - black; $\mathrm{Hg}_{\text {snow }}$ - red $)$. The regression line obtained for surface snow mercury is $\mathrm{Hg}_{\text {snow }}-0.0004 t+16.136$, while for atmospheric mercury, it is GEM $=-0.1127 t+4787.8$. Panel (b) shows the de-trended $\mathrm{Hg}$ series in surface snow (in red and orange) and atmosphere (grey and black). Panel (a) shows the correlation between de-trended $\mathrm{Hg}_{\text {snow }}$ and $\mathrm{Hg}_{\text {atm }}$ considering a $6 \mathrm{~h}$ average value. The figure is based on the same data as Fig. 3 .

The most interesting experiment is the one conducted during early April in 2016 when a day and night cycle was still present (Fig. 3). During this experiment, mercury, and iodine show a similar pattern with a distinct diurnal cycle in surface snow ( $\mathrm{I}_{\text {snow }}$ vs. $\mathrm{Hg}_{\text {snow }}, R=0.57, p$ value $<0.01$ ). For both elements, the highest concentrations were detected during the night and the lowest during the day. Iodine has been demonstrated to be active in the upper snow layer. Previous laboratory and outdoor experiments have demonstrated two photo-induced mechanisms for the release of inorganic iodine from the snowpack to the atmosphere: (i) photooxidation of iodide in ice with the resulting production of tri-iodide $\left(\mathrm{I}_{3}^{-}\right)$and evaporable molecular iodine $\left(\mathrm{I}_{2}\right)$ (Kim et al., 2016) and (ii) the emission of an iodine photo-fragments following the heterogenous photoreduction of iodate in ice (Gálvez et al., 2016). These experimental studies have shown that the 


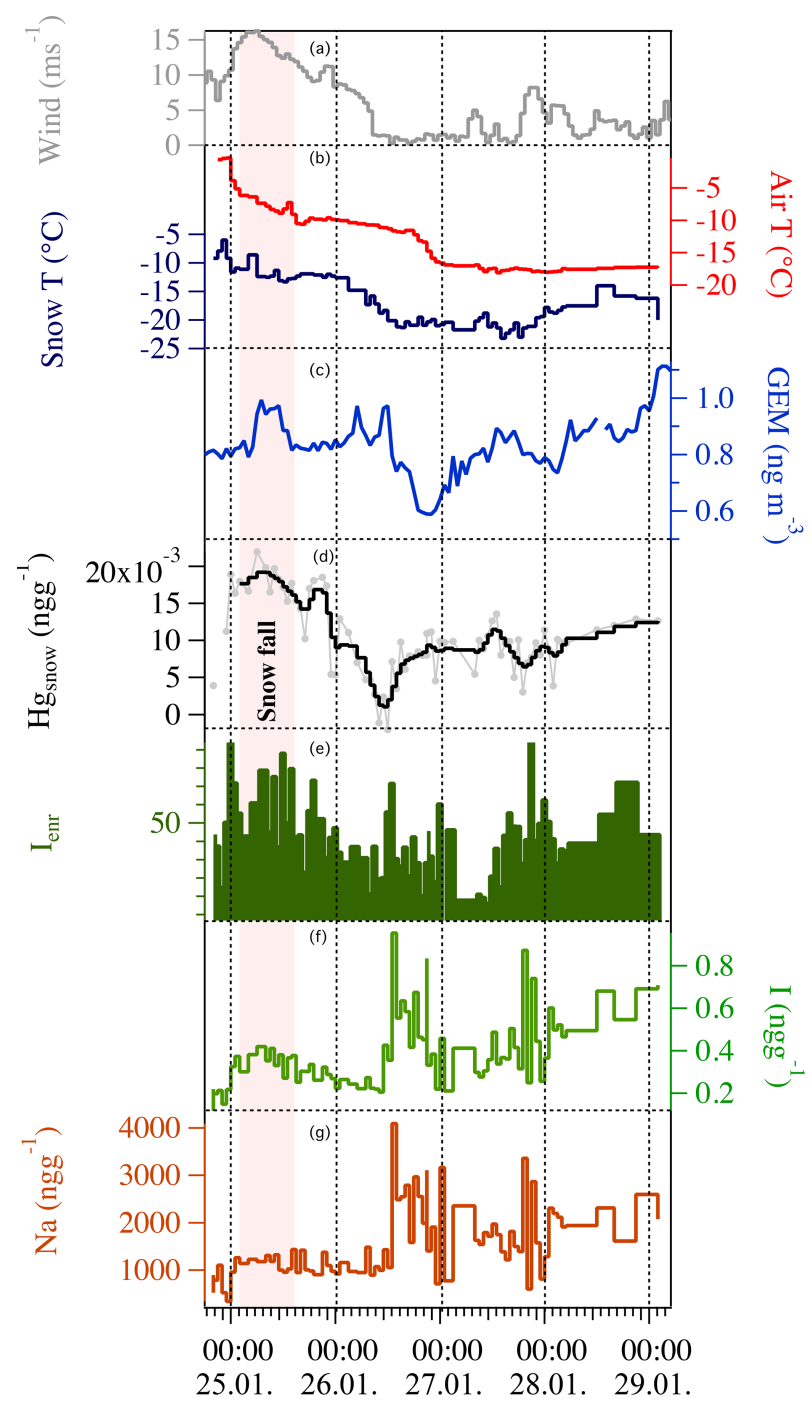

Ny-Ålesund time (January 2017)

Figure 5. The 2017 experiment was conducted during the polar night. Iodine concentration ( $\mathbf{f}-$ green line) correlated with sodium concentration ( $\mathbf{g}$ - dark red line). The iodine enrichment factor (e dark green solid line) did not exhibit any diurnal cycle and had the higher value compared to the three experiments. Gaseous elemental mercury (c - blue line) and the surface snow total mercury concentrations did not exhibit any diurnal pattern (d - light grey line for raw data and black line for three-point smoothed). Snow and air temperature (b - dark blue and red) did not show any diurnal cycle. Wind speed (a) is shown in grey. Dashed vertical lines indicate local midnight.

release of iodine from the snow or ice to the atmosphere depends on solar radiation. Indeed, (Raso et al., 2017) recently measured $\mathrm{I}_{2}$ in the Arctic atmosphere under natural sunlight conditions with results that are in agreement with the supposed photochemical production mechanisms.

Kim et al. (2016) showed that the iodide photooxidation to $\mathrm{I}_{3}^{-}$strongly depended on irradiation time following the
UV-visible absorption spectrum of iodide in ice. This would explain the observations of reduced iodine concentrations in ice during the sunlit parts of the day. Although we do not have observations of atmospheric iodine, it is very likely that snow re-emission during the day leads to a peak in reactive gas phase iodine in the overlying polar boundary layer at low solar zenith angles. The emitted gas phase iodine would then readily form reservoir species $\left(\mathrm{HOI}, \mathrm{IONO}_{2}, \mathrm{HI}\right)(\mathrm{Saiz}-$ Lopez et al., 2014) that, once photochemistry ceases, could deposit and accumulate in the snow or ice until the following sunrise, when re-emission starts again.

Active mercury recycling from the snowpack has already been suggested or observed by several authors (Dommergue et al., 2012; Durnford and Dastoor, 2011; Song et al., 2018; Steffen et al., 2008). Mercury in its oxidized forms can be deposited onto the snowpack, increasing total $\mathrm{Hg}$ concentrations in the upper snow strata. Once present in the snowpack, $\mathrm{Hg}$ is very labile, it can be reduced back to $\mathrm{Hg}(0)$ and can undergo dynamic exchange with the atmosphere above (Steffen et al., 2002). Atmospheric mercury can undergo wet or dry deposition to the snowpack, either as gaseous elemental (GEM) or oxidized mercury (GOM), and can be re-emitted as GEM (Brooks et al., 2006). Photochemical reactions are important in altering the speciation of $\mathrm{Hg}$ in the snowpack and depend on environmental properties and snowpack chemistry. Spolaor et al. (2018) shows that total $\mathrm{Hg}$ concentrations in the surface snow in the inner Antarctic Plateau do not exhibit a clear diurnal cycle as has been determined for gaseous elemental mercury (Angot et al., 2016c; Dommergue et al., 2012). However, $\mathrm{Hg}$ in surface snow shows the highest values during the insolation minima, suggesting that its concentration in the snow might be influenced by daily differences in incoming solar radiation. The experiment at Dome C (Spolaor et al., 2018) was carried out under full polar day conditions with incoming solar radiation reaching the snow surface for the entire period of the experiment. The experiment conducted at Ny-Ålesund between 6 to 9 April 2016 was characterized by a night and day cycle. Similar to iodine, a clear diurnal cycle has been detected for atmospheric and surface snow mercury. Snow mercury shows the highest concentrations during the night, with a minimum during the daytime. Contrary to this, the GEM shows a minimum during nighttime and a maximum during the daytime. This antiphase behaviour (Fig. 3 and Table 2) suggests that under daylight conditions, mercury in the surface snow can be reduced and released by photochemical processes from the snow surface, resulting in increases in atmospheric concentrations. This is not the only mechanism that can lead to increases in atmospheric concentrations. Changes in the atmospheric mixing layer height may lead to apparent concentration changes of atmospheric species, even if total amounts in the boundary layer remain constant. In the Ny-Ålesund area it is difficult to estimate the height of the boundary layer due to effects induced by winds and by the orography of the Brøgger Peninsula. However, during the experiments the stable meteorolog- 
ical conditions suggested that the atmospheric mixing height was quite stable, minimizing any influence of the boundary layer on GEM concentrations.

During the night, mercury can be oxidized to $\mathrm{Hg}$ (II) and redeposited onto the snow surface. In addition to this diurnal oscillation during the experiment, if we exclude the snowfall that caused a re-enrichment of surface snow for both elements, we detected a decreasing trend for mercury in snow as well as in the atmosphere (Fig. 4 and Table 2), from the beginning to the end of the experiment. This decreasing trend may be ascribed to re-emission during the daytime and an incomplete deposition during the night due to possible dilution or removal processes caused by the surrounding atmosphere, with air mass movements as well for mixing within the upper atmospheric strata. This suggested atmospheric removal could explain the positive correlation between GEM and snow surface $\mathrm{Hg}$ seen in Table 2 that is masking the antiphase caused by the diurnal daylight cycle. When the two series are de-trended by removing the overall decreasing trend (by considering $6 \mathrm{~h}$ average values), the correlation between atmospheric and snow mercury becomes significantly negative (Fig. 4a and Table 2).

At the end of the 2016 experiment, a snowfall event occurred (Fig. 3, pink shading). The net effect of the snowfall was to increase the mercury concentration in the upper snow surface. Precipitation events seem to be associated with elevated total $\mathrm{Hg}$ concentrations in surface snow samples (Figs. 2 and 3). Angot et al. (2016c) have suggested that the presence of ice crystals could enhance the dry deposition of $\mathrm{Hg}$ (II). Indeed, due to an elevated specific surface area, the mercury-capture efficiency of ice crystals is high (Douglas et al., 2008). Although there is a deposition of mercury to surface snow, atmospheric mercury did not show a decrease in concomitance with the snowfall but continued to show the usual diurnal pattern. In Antarctica, it has been demonstrated that snow and atmospheric mercury concentrations are related, but it should be taken into consideration that the boundary layer can be confined to the first $30 \mathrm{~m}$ above the snow surface (Angot et al., 2016a). After the snowfall the mercury surface snow concentration decreased from 45 to $8 \mathrm{pg} \mathrm{g}^{-1}$ with a net loss of $37 \mathrm{pg} \mathrm{g}^{-1}$ of total mercury in $1 \mathrm{~h}$. Assuming all snow mercury lost is lost as GEM, considering a sampling depth of $3 \mathrm{~cm}$ for an area of $1 \mathrm{~m}^{2}$ and considering an average snow density of $0.3 \mathrm{~g} \mathrm{~cm}^{-3}$, the emission rate would be $5.5 \mathrm{ng} \mathrm{m}^{-2} \mathrm{~h}^{-1}$, a similar order of magnitude to that determined by Kamp et al. (2017). It must be noted that Kamp et al. (2018) measured the total emission flux, while we focused on the upper snowpack layer; emissions from the lower or deeper strata are not considered that might contribute to the total emission from the snowpack. The mercury released from the snow after snowfall may not be enough to impact the GEM due to dilution effects. Is also possible that Zeppelin station is often located above the marine boundary layer and the mercury released from the snow is confined and is not able to influence the mercury concentration in the free troposphere. Zeppelin station is at a higher elevation (approximately $400 \mathrm{~m}$ above the sampling site) compared to the snow sampling site but is the only site giving hourly mercury atmospheric measurements in the area. Although the two sites may not be directly connected (Aspmo et al., 2005), we assume that the snow mercury and iodine release mechanisms that occur in the snow at our sampling site also occur in the snow surrounding Zeppelin station at more or less the same rates. Consequently, GEM atmospheric concentrations and the diurnal cycle should be representative of the variations in the atmospheric cycle above the surrounding sampled snow field.

Surface snow iodine concentrations, similarly to mercury, are enhanced during liquid or solid deposition. Several studies have demonstrated that rain, snow, and aerosol are enriched in soluble organic iodine as well as inorganic iodine (iodide and iodate) (Baker, 2005; Saiz-Lopez and von Glasow, 2012). Uptake of iodine species by cloud droplets and snowflakes followed by wet deposition or snowfall are major atmospheric iodine removal processes, which would enhance the concentration of iodine in the snow or ice. It is interesting to note that after the snowfall events, the enhanced concentrations in surface snow rapidly decrease. This phenomenon is more evident during the 2015 experiment (Fig. 2) when $24 \mathrm{~h}$ of solar irradiation occur. In the 2016 experiment after the snowfall, the iodine decrease is probably masked by nocturnal deposition. Bromine was also measured during the 2016 experiment (Fig. 6) to understand if, as for iodine and mercury, it can undergo surface recycling re-emission processes as suggested by previous studies (Simpson et al., 2007). Bromine shows a correlation of $r=0.85$ with sodium and the $\mathrm{Br}_{\text {enr }}$ factor (calculated as $\mathrm{Br}_{\text {enr }}=\mathrm{Br}_{\text {snow }} \times\left(\mathrm{Na}_{\text {snow }} \times\right.$ $\left.[\mathrm{Br} / \mathrm{Na}]_{\mathrm{sw}}\right)$, where $\left.\mathrm{Br} / \mathrm{Na}_{\mathrm{sw}}=0.006\right)$ does not show a diurnal cycle as for iodine (and its enrichment factor) and mercury. As has already been proposed, bromine after deposition is probably preserved in surface snow (Spolaor et al., 2014). During snowfall, both sodium and bromine decrease, most likely due to the dilution effect caused by new snowfall. It is likely that the main sodium and bromine deposition occurred by sea spray deposition caused by wave breaking (no sea ice was present in the fjord at Ny-Ålesund during the experiments, so the bromine explosion over sea ice did not occur). Windblown snow and eventual snowfall can affect the deposition of what is present in the atmosphere and dilute the concentrations in surface snow. However, it should be noted that although $\mathrm{Br}$ and $\mathrm{Na}$ surface snow concentrations decrease during snowfall, the $\mathrm{Br}$ enrichment factor increased, suggesting that snowfall is able to scavenge gas phase bromine present in the atmosphere in addition to the aerosol phase and deposit it onto the snow surface.

The experiment conducted in 2015 was characterized by full light conditions (Fig. 2) similar to those encountered in Antarctica (Spolaor et al., 2018). Both iodine and mercury in surface snow did not show any diurnal cycle suggesting that a continuous recycling process may act on the snow sur- 


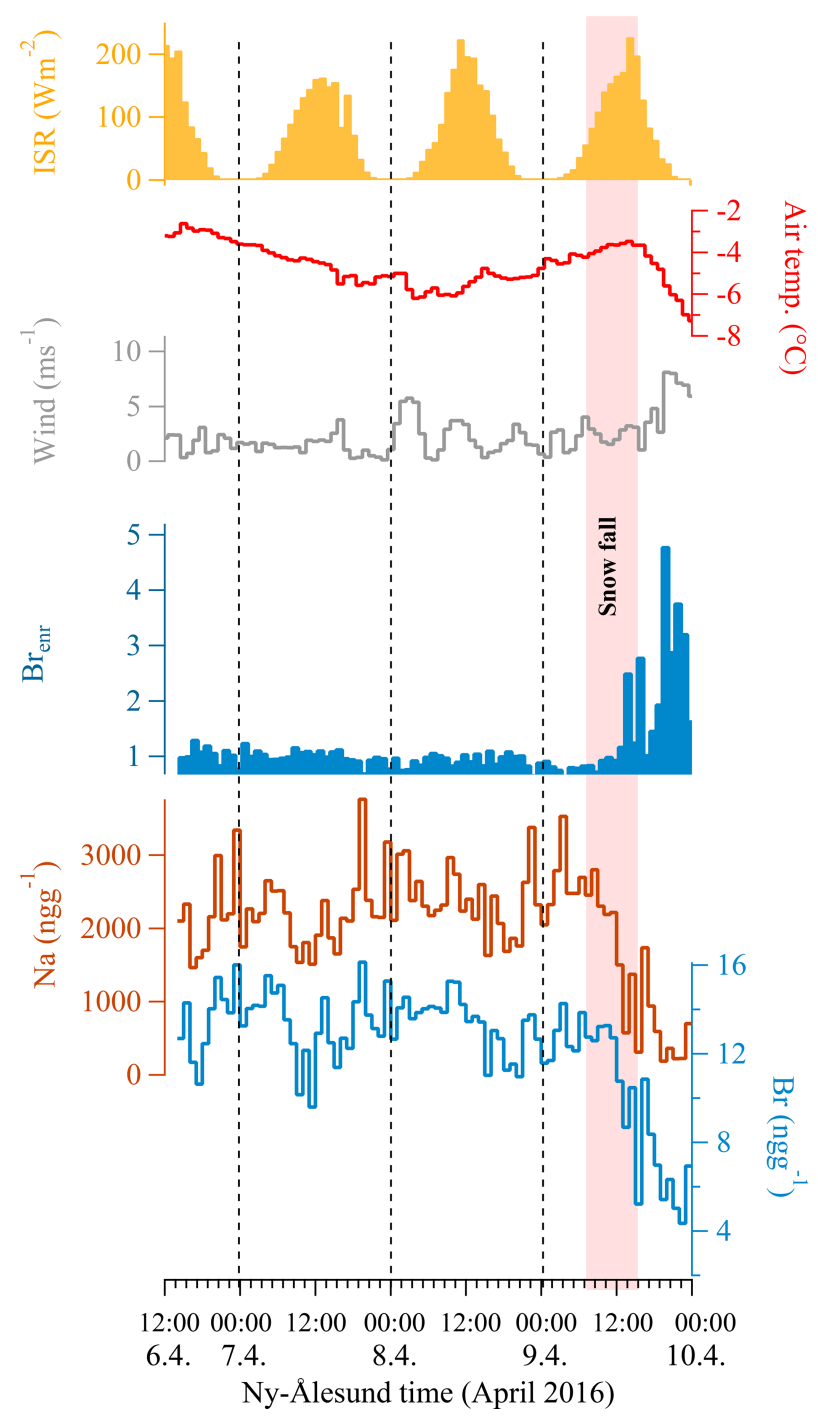

Figure 6. Surface bromine recycling during the 2016 experiment. The bromine concentration (light blue line) does not show diurnal variability and follows the sodium surface concentration (dark red line). The bromine enrichment factor (blue solid line calculated as $\mathrm{Br}_{\text {enr }}=\mathrm{Br}_{\text {snow }} /\left(\mathrm{Na}_{\text {snow }} \times 0.006\right)$ where 0.006 is the $\mathrm{Br} / \mathrm{Na}$ seawater mass ratio) does not show a diurnal cycle, but it is evident that snowfall effects the bromine concentration and its enrichment factor during snowfall (pink shading). Air temperatures do not show a pronounced diurnal cycle (red line) connected with the incoming solar radiation (solid yellow). Dashed vertical lines indicate local midnight.

face. Iodine shows an almost constant concentration in the first part of the experiment with some oscillations, connected to sodium variations and hence possible sea spray deposition, occurring in the second part of the experiment. While GEM still shows a clear diurnal cycle, the mercury in the snow does not (Fig. 2). The Hg concentration in the surface snow has some variations that are not connected with changes in incoming solar radiation. As for the 2016 experiment, during the last days of the experiment, a snowfall event occurred, causing a rapid enrichment of iodine and $\mathrm{Hg}$ in the surface snow followed by a rapid decrease most likely due to photoinduced re-emission processes.

\section{Conclusions}

Three high temporal-resolution experiments have been carried out between 2015 and 2017. The three experiments were aimed at studying the behaviour of iodine and mercury (and bromine only in 2016) in snow during the different polar seasons. One was conducted during the polar night ( 25 to 29 January 2017), one during the spring when the night and day cycle was present (6 to 10 April 2016), and one during late spring when sunlight was present for $24 \mathrm{~h}$ a day (28 April to 1 May 2015). The results obtained show that these elements have markedly different behaviours in surface snow that are mainly governed by sunlight and snow deposition. For iodine, the highest snow concentrations were detected during the winter polar night experiment (2017), while the lowest were during late spring (2015) when continuous solar radiation reaches the snow surface. For mercury the highest concentrations were detected in the winter (2017) and during late spring experiment (2015).

Our high temporal-resolution experiments did not have the aim of characterizing the average surface snow concentrations but were designed to understand the behaviour of these elements in surface snow within specific seasonal changes that can occur. A clear diurnal cycle for mercury and iodine has been determined when a day and night cycle was still present; however, for $\mathrm{Br}$ (and its enrichment factor) no diurnal cycle has been detected showing it has a more conservative behaviour in snow. Total mercury concentrations in surface snow peak during the night and decrease during the day, the opposite of their behaviour in the atmosphere. The daily variation in atmospheric GEM concentration might also be influence by changes in the boundary layer height; however, the stable meteorological conditions during the experiment tended to minimize this effect. Iodine acts similarly to mercury, peaking during the night and decreasing during the day. Considering our finding that up to $70 \%$ of the iodine present in the snow can be released to the atmosphere by photo-induced reactions, the active role of snow in providing gas phase iodine should be considered in studies of nucleation processes in the polar atmosphere.

This unique set of experiments has demonstrated for the first time the different behaviours of these target elements under different irradiation conditions and demonstrated that snow is an active substrate. The results obtained in Arctic snow could be translated to alpine regions and, more generally, anywhere in the presence of snow. The diurnal cycle determined for mercury in the Arctic, if demonstrated to be occurring in other places with high snow cover, could have an impact on water resources, with higher concentrations of 
mercury deposited in the water basin at night. These experiments have underlined some specific processes that can occur in surface snow; however, additional studies are planned to better understand the real impact of these processes on the overlying atmosphere. We hope that these results contribute to the efforts in understanding the role of the snowpack in the Arctic mercury and iodine cycles and bromine behaviour in surface snow. Understanding the behaviour of these elements in the surface snowpack may shed light on the role and the contribution of snow emissions, primarily to the marine boundary layer. For example, species such as iodine are directly active in the formation of cloud condensation nuclei that could have a direct effect on polar climate.

Data availability. The data will be available upon request to the corresponding author.

Author contributions. AS, EB, and DC conceived the experiment; AS, EB, DC, FG, and FD collected the samples; AS, CT, FL, and EB measured the samples; MMaz and MMat provided the meteorological and radiation data; KAP provided the mercury atmospheric data; AS, ASL, WRLC, and HA wrote the paper with inputs from $\mathrm{AD}, \mathrm{CB}$, and MPB.

Competing interests. The authors declare that they have no conflict of interest.

Acknowledgements. This project has received funding from the European Union's Horizon 2020 research and innovation programme under grant agreement no. 689443 via project iCUPE (Integrative and Comprehensive Understanding on Polar Environments). We are grateful to the Dirigibile Italia Arctic Station from the National Research Council - Department of Earth System Science and Environmental Technologies (CNR-DSSTTA) for logistical support. We acknowledge the help of ELGA LabWater in providing the PURELAB Pulse and PURELAB Flex, which produced the ultrapure water used in these experiments.

Financial support. This research has been supported by the European Commission (ERA-PLANET (grant no. 689443)).

Review statement. This paper was edited by Ashu Dastoor and reviewed by Henrik Skov and one anonymous referee.

\section{References}

Allan, J. D., Williams, P. I., Najera, J., Whitehead, J. D., Flynn, M. J., Taylor, J. W., Liu, D., Darbyshire, E., Carpenter, L. J., Chance, R., Andrews, S. J., Hackenberg, S. C., and McFiggans, G.: Iodine observed in new particle formation events in the Arctic atmosphere during ACCACIA, Atmos. Chem. Phys., 15, 55995609, https://doi.org/10.5194/acp-15-5599-2015, 2015.

Angot, H., Dastoor, A., De Simone, F., Gårdfeldt, K., Gencarelli, C. N., Hedgecock, I. M., Langer, S., Magand, O., Mastromonaco, M. N., Nordstrøm, C., Pfaffhuber, K. A., Pirrone, N., Ryjkov, A., Selin, N. E., Skov, H., Song, S., Sprovieri, F., Steffen, A., Toyota, K., Travnikov, O., Yang, X., and Dommergue, A.: Chemical cycling and deposition of atmospheric mercury in polar regions: review of recent measurements and comparison with models, Atmos. Chem. Phys., 16, 10735-10763, https://doi.org/10.5194/acp-16-10735-2016, 2016a.

Angot, H., Dion, I., Vogel, N., Legrand, M., Magand, O., and Dommergue, A.: Multi-year record of atmospheric mercury at Dumont d'Urville, East Antarctic coast: continental outflow and oceanic influences, Atmos. Chem. Phys., 16, 8265-8279, https://doi.org/10.5194/acp-16-8265-2016, $2016 \mathrm{~b}$.

Angot, H., Magand, O., Helmig, D., Ricaud, P., Quennehen, B., Gallée, H., Del Guasta, M., Sprovieri, F., Pirrone, N., Savarino, J., and Dommergue, A.: New insights into the atmospheric mercury cycling in central Antarctica and implications on a continental scale, Atmos. Chem. Phys., 16, 8249-8264, https://doi.org/10.5194/acp-16-8249-2016, 2016c.

Ardyna, M., Babin, M., Gosselin, M., Devred, E., Bélanger, S., Matsuoka, A., and Tremblay, J.-É.: Parameterization of vertical chlorophyll $a$ in the Arctic Ocean: impact of the subsurface chlorophyll maximum on regional, seasonal, and annual primary production estimates, Biogeosciences, 10, 4383-4404, https://doi.org/10.5194/bg-10-4383-2013, 2013.

Aspmo, K., Gauchard, P.-A., Steffen, A., Temme, C., Berg, T., Bahlmann, E., Banic, C., Dommergue, A., Ebinghaus, R., Ferrari, C., Pirrone, N., Sprovieri, F., and Wibetoe, G.: Measurements of atmospheric mercury species during an international study of mercury depletion events at Ny-Ålesund, Svalbard, spring 2003. How reproducible are our present methods?, Atmos. Environ., 39, 7607-7619, 2005.

Baker, A. R.: Marine Aerosol Iodine Chemistry: The Importance of Soluble Organic Iodine, Environ. Chem., 2, 295-298, 2005.

Björkman, M. P., Kühnel, R., Partridge, D. G., Roberts, T. J., Aas, W., Mazzola, M., Viola, A., Hodson, A., Ström, J., and Isaksson, E.: Nitrate dry deposition in Svalbard, Tellus B, 65, 12953 12976, https://doi.org/10.1002/2013JD021234, 2013.

Björkman, M. P., Vega, C. P., Kühnel, R., Spataro, F., Ianniello, A., Esposito, G., Kaiser, J., Marca, A., Hodson, A., Isaksson, E., and Roberts, T. J.: Nitrate postdeposition processes in Svalbard surface snow, J. Geophys. Res.-Atmos., 119, 12953-12976, 2014.

Brooks, S. B., Saiz-Lopez, A., Skov, H., Lindberg, S. E., Plane, J. M. C., and Goodsite, M. E.: The mass balance of mercury in the springtime arctic environment, Geophys. Res. Lett., 33, L13812, https://doi.org/10.1029/2005GL025525, 2006.

Brooks, S. B., Arimoto, R., Lindberg, S., and Southworth, G.: Antarctic polar plateau snow surface conversion of deposited oxidized mercury to gaseous elemental mercury with fractional long-term burial, Atmos. Environ., 42, 2877-2884, 2008.

Cuevas, C. A., Maffezzoli, N., Corella, J. P., Spolaor, A., Vallelonga, P., Kjær, H. A., Simonsen, M., Winstrup, M., Vinther, B., Horvat, C., Fernandez, R. P., Kinnison, D., Lamarque, J.-F., Barbante, C., and Saiz-Lopez, A.: Rapid increase in atmospheric iodine levels in the North Atlantic since the mid-20th century, Nat. Commun. 9, 1452, https://doi.org/10.1038/s41467-018-03756-1, 2018. 
Dall'Osto, M., Beddows, D. C. S., Tunved, P., Krejci, R., Ström, J., Hansson, H. C., Yoon, Y. J., Park, K.-T., Becagli, S., Udisti, R., Onasch, T., O’Dowd, C. D., Simó, R., and Harrison, R. M.: Arctic sea ice melt leads to atmospheric new particle formation, Sci. Rep., 7, 3318, https://doi.org/10.1038/s41598-017-03328-1, 2017.

Dommergue, A., Ferrari, C. P., Gauchard, P.-A., Boutron, C. F., Poissant, L., Pilote, M., Jitaru, P., and Adams, F. C.: The fate of mercury species in a sub-arctic snowpack during snowmelt, Geophys. Res. Lett., 30, 1621, https://doi.org/10.1029/2003GL017308, 2003a.

Dommergue, A., Ferrari, C. P., Poissant, L., Gauchard, P.-A., and Boutron, C. F.: Diurnal Cycles of Gaseous Mercury within the Snowpack at Kuujjuarapik/Whapmagoostui, Québec, Canada, Environ. Sci. Technol., 37, 3289-3297, 2003b.

Dommergue, A., Sprovieri, F., Pirrone, N., Ebinghaus, R., Brooks, S., Courteaud, J., and Ferrari, C. P.: Overview of mercury measurements in the Antarctic troposphere, Atmos. Chem. Phys., 10, 3309-3319, https://doi.org/10.5194/acp-10-3309-2010, 2010.

Dommergue, A., Barret, M., Courteaud, J., Cristofanelli, P., Ferrari, C. P., and Gallée, H.: Dynamic recycling of gaseous elemental mercury in the boundary layer of the Antarctic Plateau, Atmos. Chem. Phys., 12, 11027-11036, https://doi.org/10.5194/acp-1211027-2012, 2012.

Douglas, T. A., Sturm, M., Simpson, W. R., Blum, J. D., AlvarezAviles, L., Keeler, G. J., Perovich, D. K., Biswas, A., and Johnson, K.: Influence of Snow and Ice Crystal Formation and Accumulation on Mercury Deposition to the Arctic, Environ. Sci. Technol., 42, 1542-1551, 2008.

Durnford, D. and Dastoor, A.: The behavior of mercury in the cryosphere: A review of what we know from observations, J. Geophys. Res.-Atmos., 116, D06305, https://doi.org/10.1029/2010JD014809, 2011.

Faïn, X., Grangeon, S., Bahlmann, E., Fritsche, J., Obrist, D., Dommergue, A., Ferrari, C. P., Cairns, W., Ebinghaus, R., Barbante, C., Cescon, P., and Boutron, C.: Diurnal production of gaseous mercury in the alpine snowpack before snowmelt, J. Geophys. Res.-Atmos., 112, D21311, https://doi.org/10.1029/2007JD008520, 2007.

Ferrari, C. P., Gauchard, P.-A., Aspmo, K., Dommergue, A., Magand, O., Bahlmann, E., Nagorski, S., Temme, C., Ebinghaus, R., Steffen, A., Banic, C., Berg, T., Planchon, F., Barbante, C., Cescon, P., and Boutron, C. F.: Snow-to-air exchanges of mercury in an Arctic seasonal snow pack in Ny-Ålesund, Svalbard, Atmos. Environ., 39, 7633-7645, 2005.

Førland, E. J., Benestad, R., Hanssen-Bauer, I., Haugen, J. E., and Skaugen, T. E.: Temperature and Precipitation Development at Svalbard 1900-2100, Adv. Meteorol., 2011, 893790, https://doi.org/10.1155/2011/893790, 2011.

Frieß, U., Deutschmann, T., Gilfedder, B. S., Weller, R., and Platt, U.: Iodine monoxide in the Antarctic snowpack, Atmos. Chem. Phys., 10, 2439-2456, https://doi.org/10.5194/acp-102439-2010, 2010.

Gabrieli, J., Carturan, L., Gabrielli, P., Kehrwald, N., Turetta, C., Cozzi, G., Spolaor, A., Dinale, R., Staffler, H., Seppi, R., dalla Fontana, G., Thompson, L., and Barbante, C.: Impact of Po Valley emissions on the highest glacier of the Eastern European Alps, Atmos. Chem. Phys., 11, 8087-8102, https://doi.org/10.5194/acp-11-8087-2011, 2011.
Gálvez, Ó., Baeza-Romero, M. T., Sanz, M., and Saiz-Lopez, A.: Photolysis of frozen iodate salts as a source of active iodine in the polar environment, Atmos. Chem. Phys., 16, 12703-12713, https://doi.org/10.5194/acp-16-12703-2016, 2016.

Gilfedder, B. S., Petri, M., and Biester, H.: Iodine and bromine speciation in snow and the effect of orographically induced precipitation, Atmos. Chem. Phys., 7, 2661-2669, https://doi.org/10.5194/acp-7-2661-2007, 2007.

Han, Y., Huh, Y., Hong, S., Hur, S. D., and Motoyama, H.: Evidence of air-snow mercury exchange recorded in the snowpack at Dome Fuji, Antarctica, Geosci. J., 18, 105-113, 2014.

Hansen, B. B, Isaksen, K., Benestad, R. E., Kohler, J., Pedersen, A. Ø., Loe, L. E., Coulson, S. J., Larsen, J. O., and Varpe, $\varnothing .:$ Warmer and wetter winters: characteristics and implications of an extreme weather event in the High Arctic, Environ. Res. Lett., 9, 114021, https://doi.org/10.1088/17489326/9/11/114021, 2014.

Kamp, J., Skov, H., Jensen, B., and Sørensen, L. L.: Fluxes of gaseous elemental mercury (GEM) in the High Arctic during atmospheric mercury depletion events (AMDEs), Atmos. Chem. Phys., 18, 6923-6938, https://doi.org/10.5194/acp-186923-2018, 2018.

Karner, F., Obleitner, F., Krismer, T., Kohler, J., and Greuell, W.: A decade of energy and mass balance investigations on the glacier Kongsvegen, Svalbard, J. Geophys. Res.-Atmos., 118, 39864000, 2013.

Kim, K., Yabushita, A., Okumura, M., Saiz-Lopez, A., Cuevas, C. A., Blaszczak-Boxe, C. S., Min, D. W., Yoon, H.-I., and Choi, W.: Production of Molecular Iodine and Tri-iodide in the Frozen Solution of Iodide: Implication for Polar Atmosphere, Environ. Sci. Technol., 50, 1280-1287, 2016.

Kohler, J. and Aanes, R.: Effect of Winter Snow and Ground-Icing on a Svalbard Reindeer Population: Results of a Simple Snowpack Model, Arct. Antarct. Alp. Res., 36, 333-341, 2004.

Kohler, J., James, T. D., Murray, T., Nuth, C., Brandt, O., Barrand, N. E., Aas, H. F., and Luckman, A.: Acceleration in thinning rate on western Svalbard glaciers, Geophys. Res. Lett., 34, L18502, https://doi.org/10.1029/2007GL030681, 2007.

López-Moreno, J. I., Boike, J., Sanchez-Lorenzo, A., and Pomeroy, J. W.: Impact of climate warming on snow processes in $\mathrm{Ny}$ Ålesund, a polar maritime site at Svalbard, Global Planet. Change, 146, 10-21, 2016.

Lu, J. Y., Schroeder, W. H., Barrie, L. A., Steffen, A., Welch, H. E., Martin, K., Lockhart, L., Hunt, R. V., Boila, G., and Richter, A.: Magnification of atmospheric mercury deposition to polar regions in springtime: The link to tropospheric ozone depletion chemistry, Geophys. Res. Lett., 28, 3219-3222, 2001.

Maturilli, M., Herber, A., and König-Langlo, G.: Climatology and time series of surface meteorology in Ny-Ålesund, Svalbard, Earth Syst. Sci. Data, 5, 155-163, https://doi.org/10.5194/essd5-155-2013, 2013.

Mazzola, M., Tampieri, F., Viola, A. P., Lanconelli, C., and Choi, T.: Stable boundary layer vertical scales in the Arctic: observations and analyses at Ny-Ålesund, Svalbard, Q. J. Roy. Meteor. Soc., 142, 1250-1258, 2016.

Millero, F. J., Feistel, R., Wright, D. G., and McDougall, T. J.: The composition of Standard Seawater and the definition of the Reference-Composition Salinity Scale, Deep-Sea Res. Pt. I, 55, 50-72, 2008. 
Moore, C. W., Obrist, D., Steffen, A., Staebler, R. M., Douglas, T. A., Richter, A., and Nghiem, S. V.: Convective forcing of mercury and ozone in the Arctic boundary layer induced by leads in sea ice, Nature, 506, 81-84, 2014.

Moroni, B., Becagli, S., Bolzacchini, E., Busetto, M., Cappelletti, D., Crocchianti, S., Ferrero, L., Frosini, D., Lanconelli, C., Lupi, A., Maturilli, M., Mazzola, M., Perrone, M. G., Sangiorgi, G., Traversi, R., Udisti, R., Viola, A., and Vitale, V.: Vertical Profiles and Chemical Properties of Aerosol Particles upon Ny-Ålesund (Svalbard Islands), Adv. Meteorol., 2015, 292081, https://doi.org/10.1155/2015/292081, 2015.

Moroni, B., Cappelletti, D., Crocchianti, S., Becagli, S., Caiazzo, L., Traversi, R., Udisti, R., Mazzola, M., Markowicz, K., Ritter, C., and Zielinski, T.: Morphochemical characteristics and mixing state of long range transported wildfire particles at Ny-Ålesund (Svalbard Islands), Atmos. Environ., 156, 135-145, 2017.

Obrist, D., Agnan, Y., Jiskra, M., Olson, C. L., Colegrove, D. P., Hueber, J., Moore, C. W., Sonke, J. E., and Helmig, D.: Tundra uptake of atmospheric elemental mercury drives Arctic mercury pollution, Nature, 547, 201-204, https://doi.org/10.1038/nature22997, 2017.

Planchon, F. A. M., Gabrielli, P., Gauchard, P. A., Dommergue, A., Barbante, C., Cairns, W. R. L., Cozzi, G., Nagorski, S. A., Ferrari, C. P., Boutron, C. F., Capodaglio, G., Cescon, P., Varga, A., and Wolff, E. W.: Direct determination of mercury at the subpicogram per gram level in polar snow and ice by ICP-SFMS, J. Anal. Atom. Spectrom., 19, 823-830, 2004.

Poulain, A. J., Amyot, M., Findlay, D., Telor, S., Barkay, T., and Hintelmann, H.: Biological and photochemical production of dissolved gaseous mercury in a boreal lake, Limnol. Oceanogr., 49, 2265-2275, 2004.

Raso, A. R. W., Custard, K. D., May, N. W., Tanner, D., Newburn, M. K., Walker, L., Moore, R. J., Huey, L. G., Alexander, L., Shepson, P. B., and Pratt, K. A.: Active molecular iodine photochemistry in the Arctic, P. Natl. Acad. Sci. USA, 114, 10053, https://doi.org/10.1073/pnas.1702803114, 2017.

Saiz-Lopez, A. and von Glasow, R.: Reactive halogen chemistry in the troposphere, Chem. Soc. Rev., 41, 6448-6472, 2012.

Saiz-Lopez, A., Plane, J. M. C., McFiggans, G., Williams, P. I., Ball, S. M., Bitter, M., Jones, R. L., Hongwei, C., and Hoffmann, T.: Modelling molecular iodine emissions in a coastal marine environment: the link to new particle formation, Atmos. Chem. Phys., 6, 883-895, https://doi.org/10.5194/acp-6-883-2006, 2006.

Saiz-Lopez, A., Mahajan, A. S., Salmon, R. A., Bauguitte, S. J. B., Jones, A. E., Roscoe, H. K., and Plane, J. M. C.: Boundary Layer Halogens in Coastal Antarctica, Science, 317, 348-351, 2007.

Saiz-Lopez, A., Plane, J. M. C., Baker, A. R., Carpenter, L. J., von Glasow, R., Gomez Martin, J. C., McFiggans, G., and Saunders, R. W.: Atmospheric Chemistry of Iodine, Chem. Rev., 112, 1773-1804, 2012.

Saiz-Lopez, A., Fernandez, R. P., Ordóñez, C., Kinnison, D. E., Gómez Martín, J. C., Lamarque, J.-F., and Tilmes, S.: Iodine chemistry in the troposphere and its effect on ozone, Atmos. Chem. Phys., 14, 13119-13143, https://doi.org/10.5194/acp-1413119-2014, 2014.

Saiz-Lopez, A., Plane, J. M. C., Cuevas, C. A., Mahajan, A. S., Lamarque, J.-F., and Kinnison, D. E.: Nighttime atmospheric chemistry of iodine, Atmos. Chem. Phys., 16, 15593-15604, https://doi.org/10.5194/acp-16-15593-2016, 2016.
Saiz-Lopez, A., Sitkiewicz, S. P., Roca-Sanjuán, D., Oliva-Enrich, J. M., Dávalos, J. Z., Notario, R., Jiskra, M., Xu, Y., Wang, F., Thackray, C. P., Sunderland, E. M., Jacob, D. J., Travnikov, O., Cuevas, C. A., Acuña, A. U., Rivero, D., Plane, J. M. C., Kinnison, D. E., and Sonke, J. E.: Photoreduction of gaseous oxidized mercury changes global atmospheric mercury speciation, transport and deposition, Nat. Commun., 9, 4796, https://doi.org/10.1038/s41467-018-07075-3, 2018.

Schroeder, W. H. and Munthe, J.: Atmospheric mercury - An overview, Atmos. Environ., 32, 809-822, 1998.

Sherman, L. S., Blum, J. D., Johnson, K. P., Keeler, G. J., Barres, J. A., and Douglas, T. A.: Mass-independent fractionation of mercury isotopes in Arctic snow driven by sunlight, Nat. Geosci., 3, 173-177, 2010.

Simpson, W. R., von Glasow, R., Riedel, K., Anderson, P., Ariya, P., Bottenheim, J., Burrows, J., Carpenter, L. J., Frieß, U., Goodsite, M. E., Heard, D., Hutterli, M., Jacobi, H.-W., Kaleschke, L., Neff, B., Plane, J., Platt, U., Richter, A., Roscoe, H., Sander, R., Shepson, P., Sodeau, J., Steffen, A., Wagner, T., and Wolff, E.: Halogens and their role in polar boundary-layer ozone depletion, Atmos. Chem. Phys., 7, 4375-4418, https://doi.org/10.5194/acp7-4375-2007, 2007.

Sipilä, M., Sarnela, N., Jokinen, T., Henschel, H., Junninen, H., Kontkanen, J., Richters, S., Kangasluoma, J., Franchin, A., Peräkylä, O., Rissanen, M. P., Ehn, M., Vehkamäki, H., Kurten, T., Berndt, T., Petäjä, T., Worsnop, D., Ceburnis, D., Kerminen, V.-M., Kulmala, M., and O'Dowd, C.: Molecular-scale evidence of aerosol particle formation via sequential addition of $\mathrm{HIO}_{3}$, Nature, 537, 532-534, https://doi.org/10.1038/nature19314, 2016.

Skov, H., Brooks, S. B., Goodsite, M. E., Lindberg, S. E., Meyers, T. P., Landis, M. S., Larsen, M. R. B., Jensen, B., McConville, G., and Christensen, J.: Fluxes of reactive gaseous mercury measured with a newly developed method using relaxed eddy accumulation, Atmos. Environ., 40, 5452-5463, 2006.

Song, S., Angot, H., Selin, N. E., Gallée, H., Sprovieri, F., Pirrone, N., Helmig, D., Savarino, J., Magand, O., and Dommergue, A.: Understanding mercury oxidation and air-snow exchange on the East Antarctic Plateau: a modeling study, Atmos. Chem. Phys., 18, 15825-15840, https://doi.org/10.5194/acp-18-158252018, 2018.

Spolaor, A., Gabrieli, J., Martma, T., Kohler, J., Björkman, M. B., Isaksson, E., Varin, C., Vallelonga, P., Plane, J. M. C., and Barbante, C.: Sea ice dynamics influence halogen deposition to Svalbard, The Cryosphere, 7, 1645-1658, https://doi.org/10.5194/tc7-1645-2013, 2013a.

Spolaor, A., Vallelonga, P., Plane, J. M. C., Kehrwald, N., Gabrieli, J., Varin, C., Turetta, C., Cozzi, G., Kumar, R., Boutron, C., and Barbante, C.: Halogen species record Antarctic sea ice extent over glacial-interglacial periods, Atmos. Chem. Phys., 13, 66236635, https://doi.org/10.5194/acp-13-6623-2013, 2013b.

Spolaor, A., Vallelonga, P., Gabrieli, J., Martma, T., Björkman, M. P., Isaksson, E., Cozzi, G., Turetta, C., Kjær, H. A., Curran, M. A. J., Moy, A. D., Schönhardt, A., Blechschmidt, A.-M., Burrows, J. P., Plane, J. M. C., and Barbante, C.: Seasonality of halogen deposition in polar snow and ice, Atmos. Chem. Phys., 14, 96139622, https://doi.org/10.5194/acp-14-9613-2014, 2014.

Spolaor, A., Barbaro, E., Christille, J. M., Kirchgeorg, T., Giardi, F., Cappelletti, D., Turetta, C., Bernagozzi, A., Björkman, M. P., 
Bertolini, E., and Barbante, C.: Evolution of the Svalbard annual snow layer during the melting phase, Rend. Lincei, 27, 1-8, https://doi.org/10.1007/s12210-015-0500-8, 2016a.

Spolaor, A., Opel, T., McConnell, J. R., Maselli, O. J., Spreen, G., Varin, C., Kirchgeorg, T., Fritzsche, D., Saiz-Lopez, A., and Vallelonga, P.: Halogen-based reconstruction of Russian Arctic sea ice area from the Akademii Nauk ice core (Severnaya Zemlya), The Cryosphere, 10, 245-256, https://doi.org/10.5194/tc-10245-2016, 2016 b.

Spolaor, A., Vallelonga, P., Turetta, C., Maffezzoli, N., Cozzi, G., Gabrieli, J., Barbante, C., Goto-Azuma, K., Saiz-Lopez, A., Cuevas, C. A., and Dahl-Jensen, D.: Canadian Arctic sea ice reconstructed from bromine in the Greenland NEEM ice core, Sci. Rep., 6, 33925, https://doi.org/10.1038/srep33925, 2016c.

Spolaor, A., Angot, H., Roman, M., Dommergue, A., Scarchilli, C., Vardè, M., Del Guasta, M., Pedeli, X., Varin, C., Sprovieri, F., Magand, O., Legrand, M., Barbante, C., and Cairns, W. R. L.: Feedback mechanisms between snow and atmospheric mercury: Results and observations from field campaigns on the Antarctic plateau, Chemosphere, 197, 306-317, 2018.

Steffen, A., Schroeder, W., Bottenheim, J., Narayan, J., and Fuentes, J. D.: Atmospheric mercury concentrations: measurements and profiles near snow and ice surfaces in the Canadian Arctic during Alert 2000, Atmos. Environ., 36, 2653-2661, 2002.

Steffen, A., Douglas, T., Amyot, M., Ariya, P., Aspmo, K., Berg, T., Bottenheim, J., Brooks, S., Cobbett, F., Dastoor, A., Dommergue, A., Ebinghaus, R., Ferrari, C., Gardfeldt, K., Goodsite, M. E., Lean, D., Poulain, A. J., Scherz, C., Skov, H., Sommar, J., and Temme, C.: A synthesis of atmospheric mercury depletion event chemistry in the atmosphere and snow, Atmos. Chem. Phys., 8, 1445-1482, https://doi.org/10.5194/acp-8-1445-2008, 2008.
Udisti, R., Bazzano, A., Becagli, S., Bolzacchini, E., Caiazzo, L., Cappelletti, D., Ferrero, L., Frosini, D., Giardi, F., Grotti, M., Lupi, A., Malandrino, M., Mazzola, M., Moroni, B., Severi, M., Traversi, R., Viola, A., and Vitale, V.: Sulfate source apportionment in the Ny-Ålesund (Svalbard Islands) Arctic aerosol, Rend. Lincei, 27, 85-94, 2016.

Vecchiato, M., Barbaro, E., Spolaor, A., Burgay, F., Barbante, C., Piazza, R., and Gambaro, A.: Fragrances and PAHs in snow and seawater of Ny-Ålesund (Svalbard): Local and long-range contamination, Environ. Pollut., 242, 1740-1747, 2018.

Wang, J., Zhang, L., and Xie, Z.: Total gaseous mercury along a transect from coastal to central Antarctic: Spatial and diurnal variations, J. Hazard. Mater., 317, 362-372, 2016.

Westermann, S., Boike, J., Langer, M., Schuler, T. V., and Etzelmüller, B.: Modeling the impact of wintertime rain events on the thermal regime of permafrost, The Cryosphere, 5, 945-959, https://doi.org/10.5194/tc-5-945-2011, 2011.

Zangrando, R., Barbaro, E., Zennaro, P., Rossi, S., Kehrwald, N. M., Gabrieli, J., Barbante, C., and Gambaro, A.: Molecular Markers of Biomass Burning in Arctic Aerosols, Environ. Sci. Technol., 47, 8565-8574, 2013. 